Article

\title{
Elastic Parameters of Paramagnetic Fe-20Cr-20Ni-Based Alloys: A First-Principles Study
}

\author{
Noura Al-Zoubi \\ Department of Applied Physics, Tafila Technical University, Tafila 66110, Jordan; noura@ttu.edu.jo
}

Received: 26 June 2019; Accepted: 11 July 2019; Published: 17 July 2019

check for

updates

\begin{abstract}
The single-crystal and polycrystalline elastic parameters of paramagnetic $\mathrm{Fe}_{0.6-x} \mathrm{Cr}_{0.2} \mathrm{Ni}_{0.2} \mathrm{M}_{x}(\mathrm{M}=\mathrm{Al}, \mathrm{Co}, \mathrm{Cu}, \mathrm{Mo}, \mathrm{Nb}, \mathrm{Ti}, \mathrm{V}$, and $\mathrm{W} ; 0 \leq x \leq 0.08)$ alloys in the face-centered cubic (fcc) phase were derived by first-principles electronic structure calculations using the exact muffin-tin orbitals method. The disordered local magnetic moment approach was used to model the paramagnetic phase. The theoretical elastic parameters of the present $\mathrm{Fe}-\mathrm{Cr}-\mathrm{Ni}$-based random alloys agree with the available experimental data. In general, we found that all alloying elements have a significant effect on the elastic properties of $\mathrm{Fe}-\mathrm{Cr}-\mathrm{Ni}$ alloy, and the most significant effect was found for $C$. A correlation between the tetragonal shear elastic constant $C^{\prime}$ and the structural energy difference $\Delta E$ between fcc and bcc lattices was demonstrated. For all alloys, small changes in the Poisson's ratio were obtained. We investigated the brittle/ductile transitions formulated by the Pugh ratio. We demonstrate that $\mathrm{Al}, \mathrm{Cu}, \mathrm{Mo}, \mathrm{Nb}, \mathrm{Ti}, \mathrm{V}$, and $\mathrm{W}$ dopants enhance the ductility of the $\mathrm{Fe}-\mathrm{Cr}-\mathrm{Ni}$ system, while Co reduces it. The present theoretical data can be used as a starting point for modeling the mechanical properties of austenitic stainless steels at low temperatures.
\end{abstract}

Keywords: exact muffin-tin orbitals method; austenitic stainless steel; elastic constants; random alloys; density functional theory

\section{Introduction}

Austenitic stainless steels are paramagnetic alloys having the face-centered cubic (fcc) crystallographic structure. They are mainly composed of Fe, a minimum of 12 atomic percentage of chromium, a minimum of 6 atomic percentage of $\mathrm{Ni}$, and low amounts of carbon and nitrogen. Austenitic stainless steels have excellent corrosion resistance and good mechanical properties such as ductility, strength, stiffness, and toughness [1]. Austenitic stainless steels have a wide range of applications, such as kitchen utensils, construction, equipment for the chemical industry and food processing, heat exchangers, etc. [2].

Single-crystal and polycrystalline elastic parameters are essential in determining the mechanical properties of the materials, such as hardness, fracture, ductility, and brittleness. These parameters measure the resistance of materials to external forces, and they determine the bulk modulus $B$, shear modulus $G$, Young's modulus $E$, and Poisson's ratio $v$. Alloying is important in tuning the fundamental properties of materials and in designing advanced engineering materials. Different alloying elements have specific effects on the materials. In austenitic stainless steels, the major alloying elements are chromium and nickel. Chromium gives the austenitic stainless steels corrosion resistance [3], while nickel is added to austenitic stainless steels to promote the austenite microstructure and to increase the ductility and toughness of steels. Other alloying elements determine the property profiles of certain grades of austenitic stainless steels. Many experimental studies have investigated the elastic properties of austenitic stainless steels [4-8]. In contrast to the experimental side, there are only a few theoretical studies of the elastic properties of austenitic stainless steels [9-11]. The principal purpose of this first-principles study is to fill this gap and to provide a comprehensive database 
of the alloying effects on the elastic parameters of paramagnetic fcc Fe-20Cr-20Ni- $x$ M. Specifically, we investigated the changes in the single-crystal and polycrystalline elastic constants caused by adding small concentrations of $\mathrm{M}(\mathrm{M}=\mathrm{Al}, \mathrm{Co}, \mathrm{Cu}, \mathrm{Mo}, \mathrm{Nb}, \mathrm{V}$, and $\mathrm{W} ; 0 \leq x \leq 8$, where $x$ is in atom \%) that are soluble in the $\mathrm{Fe}-\mathrm{Cr}-\mathrm{Ni}$ system. We chose these alloying elements since they represent simple metal $(\mathrm{Al})$, as well as nonmagnetic $(\mathrm{Cu}, \mathrm{Mo}, \mathrm{Nb}, \mathrm{V}$, and $\mathrm{W})$ and magnetic $(\mathrm{Co})$ transition metals. We excluded $\mathrm{Cr}$ and $\mathrm{Ni}$ from this study, since the effects of these alloying elements on the elastic properties of a paramagnetic fcc Fe-Cr-Ni system were discussed previously by Vitos et al. [11].

In the present work, all quaternary alloys were treated as substitutional disordered paramagnetic solid solutions with an ideal fcc structure. The paramagnetic phase was modeled using a disordered local moment scheme, which describes the systems well above the magnetic transition temperatures.

The rest of the paper includes two sections and conclusions. In Section 2, we describe the ab initio method, the elastic parameters, and the details of the numerical calculations. We present the results and the discussion in Section 3.

\section{Methodology}

\subsection{Total Energy Calculations}

The calculations in this work are based on density functional theory [12,13] and the Perdew-Burke-Ernzerhof (PBE) generalized gradient approximation [14] for the exchange correlation functional. The exact muffin-tin orbitals (EMTO) method [10,15-19] in combination with the scalar-relativistic scheme and soft-core approximation was used to solve the Kohn-Sham equations. The chemical and magnetic substitutional disorder was treated using coherent potential approximation (CPA) [20,21]. The total energy was computed using full charge density (FCD) approximation [22]. The paramagnetic state of the $\mathrm{Fe}-\mathrm{Cr}-\mathrm{Ni}-\mathrm{M}$ alloys was simulated by the disordered local moments (DLM) model [23]. Within the DLM picture, a paramagnetic Fe-Cr-Ni-M quaternary alloy is described as an eight-component $\left(\mathrm{Fe}^{\uparrow} \mathrm{Fe}^{\downarrow}\right)_{0.6-x}\left(\mathrm{Cr}^{\uparrow} \mathrm{Cr}^{\downarrow}\right)_{0.2}\left(\mathrm{Ni}^{\uparrow} \mathrm{Ni}^{\downarrow}\right)_{0.2}\left(\mathrm{M}^{\uparrow} \mathrm{M}^{\downarrow}\right)_{x}$ alloy with equal amounts of spin up $(\uparrow)$ and spin down $(\downarrow)$ components. Using the DLM scheme, the impact of the loss of the magnetic moment above the Curie temperature on the total energy is properly taken into account, although our calculations were formally still performed at $0 \mathrm{~K}$.

The equations of state and elastic parameters of the present Fe-based alloys and transition metal alloys were calculated using the EMTO method which was used in several former works $[9,11,24-31]$.

\subsection{Elastic Constants}

The elastic properties of mono-crystalline materials are described by the elements $C_{i j}$ of the elasticity tensor. There are three independent elastic constants for a cubic lattice $C_{11}, C_{12}$, and $C_{44}$ and they are connected to the tetragonal shear elastic constant $C^{\prime}=\left(C_{11}-C_{12}\right) / 2$ and bulk modulus $B=\left(C_{11}\right.$ $+2 C_{12}$ )/3. Dynamical (mechanical) stability requires that $C_{44}>0, C^{\prime}>0$, and $B>0$.

The cubic shear elastic constants $C^{\prime}$ and $C_{44}$ were computed by keeping the volume constant during deformations of the conventional cubic cell. For the tetragonal shear modulus $C^{\prime}$, the following orthorhombic deformation was used:

$$
\left(\begin{array}{ccc}
1+\delta_{o} & 0 & 0 \\
0 & 1-\delta_{o} & 0 \\
0 & 0 & \frac{1}{1-\delta_{o}^{2}}
\end{array}\right)
$$

This leads to the energy change

$$
\Delta E\left(\delta_{o}\right)=2 V C^{\prime} \delta_{o}^{2}+O\left(\delta_{o}^{4}\right) .
$$


The $C_{44}$ shear modulus was determined from the monoclinic distortion

$$
\left(\begin{array}{ccc}
1 & \delta_{m} & 0 \\
\delta_{m} & 1 & 0 \\
0 & 0 & \frac{1}{1-\delta_{m}^{2}}
\end{array}\right)
$$

yielding

$$
\Delta E\left(\delta_{m}\right)=2 V C_{44} \delta_{m}^{2}+O\left(\delta_{m}^{4}\right)
$$

In the above expressions, $\delta$ is the strain parameter.

Figure 1a,b represents an example of polynomial fit carried out for the above two equations (Equations (1) and (2)) which represent the constant volume (equilibrium volume) total energy change as functions of orthorhombic and monoclinic deformations, respectively. Panels (c) and (d) in Figure 1 show the standard errors in $C^{\prime}$ and $C_{44}$, respectively, of paramagnetic fcc $\mathrm{Fe}-\mathrm{Cr}-\mathrm{Ni}-\mathrm{Al}$ alloys based on the polynomial fit.
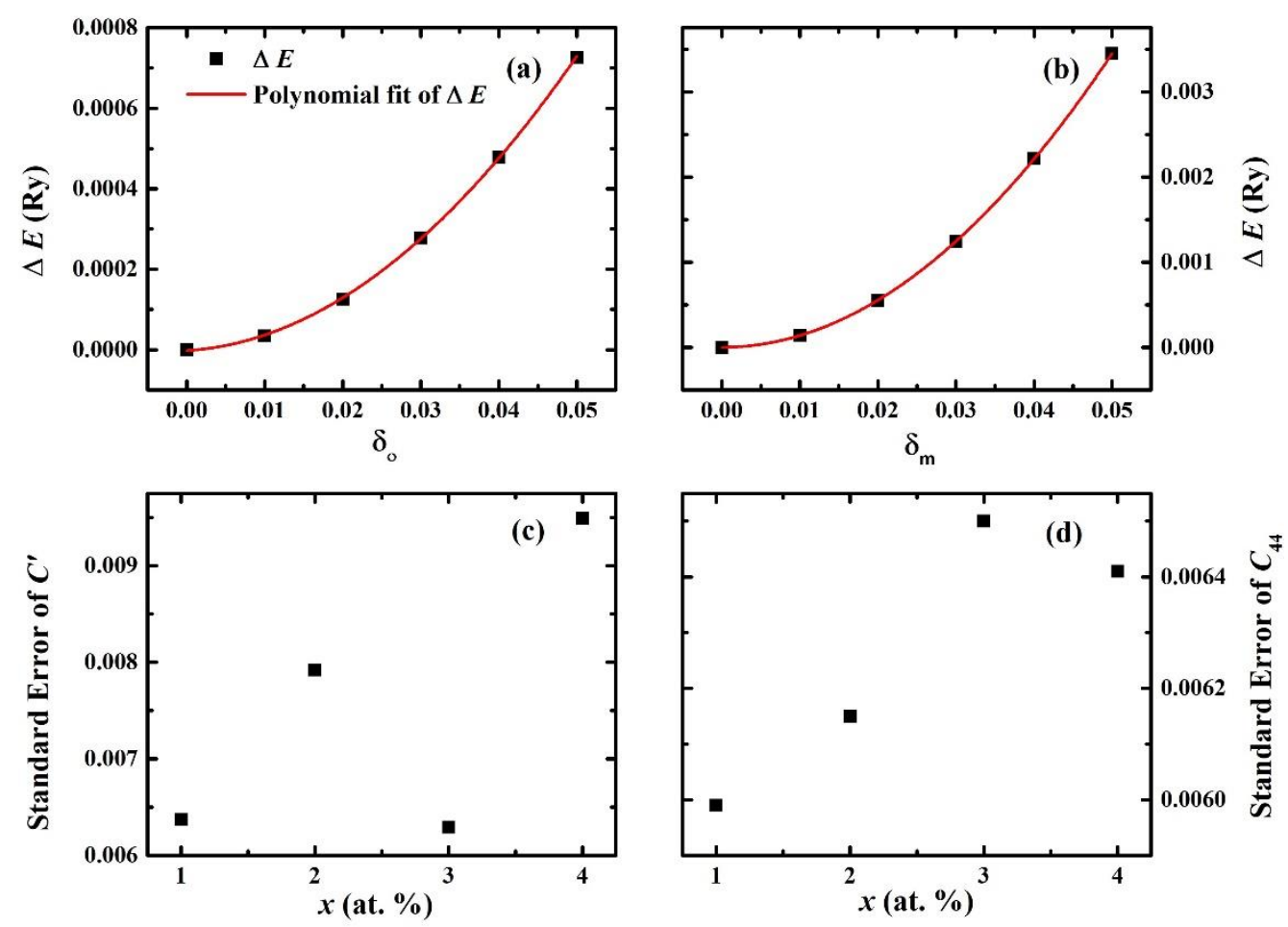

Figure 1. (a) Total energy change (Equation (1)) as a function of orthorhombic deformation $\delta_{\mathrm{o}}$ of the fcc structure of a paramagnetic $\mathrm{Fe}_{0.59} \mathrm{Cr}_{0.2} \mathrm{Ni}_{0.2} \mathrm{Al}_{0.01}$ alloy. (b) Total energy change (Equation (2)) as a function of the monoclinic deformation $\delta_{\mathrm{m}}$ of the fcc structure of a paramagnetic $\mathrm{Fe}_{0.59} \mathrm{Cr}_{0.2} \mathrm{Ni}_{0.2} \mathrm{Al}_{0.01}$ alloy. The red curves in (a) and (b) represent the polynomial fit of the total energy change. (c) The standard error in $C^{\prime}$ and (d) the standard error in $C_{44}$ of $\mathrm{Fe}_{0.6-x} \mathrm{Cr}_{0.2} \mathrm{Ni}_{0.2} \mathrm{Al}_{x}(x=0.01,0.02,0.03,0.04)$ alloys as a function of $x$.

In polycrystalline materials, the mono-crystalline grains are misoriented. On a large scale, these materials can be considered as isotropic materials. The isotropic solids can be described by their bulk modulus $B$ and shear modulus $G$. One can establish the ab initio polycrystalline elastic moduli by transforming single-crystal elastic constants $C_{i j}$ to macroscopic quantities by suitable averaging methods based on statistical mechanics. For a cubic lattice, the polycrystalline bulk modulus is identical to the single-crystal bulk modulus. For the shear modulus, there are several different techniques for 
averaging the single-crystal data. Here, we adopted the arithmetic Hill [32] average $G=\left(G_{V}+G_{R}\right) / 2$, where the Voigt [33] and Reuss [34] limits are given in terms of single-crystal elastic constants, namely,

$$
\begin{gathered}
G_{\mathrm{R}}=5\left(C_{11}-C_{12}\right) C_{44} /\left(4 C_{44}+3 C_{11}-3 C_{12}\right) \\
G_{V}=\left(C_{11}-C_{12}+3 C_{44}\right) / 5
\end{gathered}
$$

The Young's modulus $E$ and Poisson's ratio $v$ are related to $B$ and $G$ by the relations

$$
\begin{gathered}
E=9 B G /(3 B+G) \\
v=(3 B-2 G) /(6 B+2 G)
\end{gathered}
$$

In the present study, the single-crystal and polycrystalline elastic constants of the paramagnetic $\mathrm{Fe}_{0.6-x} \mathrm{Cr}_{0.2} \mathrm{Ni}_{0.2} \mathrm{M}_{x}$ (where $\mathrm{M}=\mathrm{Al}, \mathrm{Co}, \mathrm{Cu}, \mathrm{Mo}, \mathrm{Nb}, \mathrm{Ti}, \mathrm{V}$, and $\mathrm{W} ; 0 \leq x \leq 0.08$ ) quaternary alloys were calculated for fcc lattices. The properties are presented and analyzed as a function of the atomic concentration $x$. Different atomic concentrations were used for each alloying element depending on their real solubility in austenitic $\mathrm{Fe}_{0.6-x} \mathrm{Cr}_{0.2} \mathrm{Ni}_{0.2} \mathrm{M}$ stainless steel.

\subsection{Numerical Details}

Green's function was computed for 16 complex energy points distributed exponentially on a semicircular contour. The $s, p, d$, and $f$ orbitals were included in the EMTO basis set and $l_{\max }^{h}=8$ was used in the one-center expansion of the full charge density [10]. The calculations are presented for paramagnetic fcc alloys. The total energy was evaluated by the shape function technique. The screened impurity model [35] with a screening parameter of 0.6 was used to describe the electrostatic correction to the single-site coherent potential approximation. For all components of the alloy, we chose the radii of the potential spheres to be equal to the corresponding average radii of the atomic spheres.

The bulk moduli of $\mathrm{Fe}_{0.6-} \mathrm{Cr}_{0.2} \mathrm{Ni}_{0.2} \mathrm{M}_{x}$ alloys at their equilibrium volumes estimated from Equation (7) were derived from an exponential Morse-type function [36] installed with the ab initio total energies calculated for seven different atomic volumes; these volumes were expressed in terms of Wigner-Seitz radii $w$ in the range $2.55 \mathrm{Bohr} \leq w \leq 2.70 \mathrm{Bohr}$ in steps of $0.025 \mathrm{Bohr}$, including the equilibrium Wigner-Seitz radius. We considered six orthorhombic and monoclinic distortions with $\delta=0,0.01,0.02,0.03,0.04$, and 0.05 . We used 1331-1694 uniformly distributed $k$-points in the irreducible wedge of the monoclinic and orthorhombic Brillouin zones to get the accuracy needed for the calculation of elastic constants.

\section{Results and Discussions}

\subsection{Assessing the Accuracy of the Paramagnetic fcc Fe-20Cr-20Ni Alloy}

We started our study by assessing the accuracy of our method with available experimental methods. In Table 1, we compare our results of single-crystal and polycrystalline elastic constants for the $\mathrm{Fe}_{0.6} \mathrm{Cr}_{0.2} \mathrm{Ni}_{0.2}$ alloy with the experimental results [8] for the $\mathrm{Fe}_{0.62} \mathrm{Cr}_{0.19} \mathrm{Ni}_{0.19}$ alloy, which is the closest alloy that we found to compare with. All theoretical elastic parameters for the $\mathrm{Fe}_{0.6} \mathrm{Cr}_{0.2} \mathrm{Ni}_{0.2}$ alloy were calculated at the lattice parameter $\mathrm{a}=3.58 \AA$ estimated from Equation (7), and the experimental elastic parameters for the $\mathrm{Fe}_{0.62} \mathrm{Cr}_{0.19} \mathrm{Ni}_{0.19}$ alloy were calculated at their experimental volume a $=3.55 \AA$ [8]. We obtained agreement between our results and the experimental results, and we found that the theoretical $C_{11}, C_{12}$, and $C^{\prime}$ values were smaller than the experimental values by $13.2 \%, 6.8 \%$, and $25.1 \%$, respectively. The calculated $C_{44}$ was larger than the experimental value by $3.9 \%$. We ascribe the worse agreement in the case of $C^{\prime}$ to the different experimental volumes used in both methods and to the small differences in concentrations of alloying elements in both systems. The theoretical polycrystalline elastic constants $B, E$, and $G$ were smaller than the experimental values by $9.4 \%, 9.2 \%$, and $9.2 \%$, respectively. On the other hand, the $B / G$ ratio and Poisson's ratio $v$ were 
accurately reproduced by our method. Compared to the experiment data, they deviated by $0.27 \%$ and $0.17 \%$, respectively.

Table 1. Theoretical (exact muffin-tin orbitals, EMTO) and experimental (Exp) [8] elastic constants (in GPa) for paramagnetic fcc $\mathrm{Fe}-\mathrm{Cr}-\mathrm{Ni}$ alloys. $\mathrm{B} / \mathrm{G}$ and $v$ are dimensionless. In the last row, we present the percentage error between the experimental and theoretical elastic constants.

\begin{tabular}{cccccccccc}
\hline System & $\boldsymbol{C}_{\mathbf{1 1}}$ & $\boldsymbol{C}_{\mathbf{1 2}}$ & $\boldsymbol{C}^{\prime}$ & $\boldsymbol{C}_{\mathbf{4 4}}$ & $\boldsymbol{B}$ & $\boldsymbol{E}$ & $\boldsymbol{G}$ & $\boldsymbol{B} / \boldsymbol{G}$ & $\boldsymbol{v}$ \\
\hline $\mathrm{Fe}_{0.6} \mathrm{Cr}_{0.2} \mathrm{Ni}_{0.2}(\mathrm{EMTO})$ & 177 & 124 & 26.6 & 131 & 142 & 181 & 70.1 & 2.03 & 0.288 \\
\hline $\mathrm{Fe}_{0.62} \mathrm{Cr}_{0.19} \mathrm{Ni}_{0.19}(\mathrm{Exp})$ & 204 & 133 & 35.5 & 126 & 157 & 199 & 77.2 & 2.03 & 0.289 \\
\hline Percentage error (\%) & 13.2 & 6.8 & 25.1 & 3.9 & 9.4 & 9.2 & 9.2 & 0.27 & 0.17 \\
\hline
\end{tabular}

Having demonstrated the accuracy of our method, we expanded our study to $\mathrm{Fe}-\mathrm{Cr}-\mathrm{Ni}$ systems containing different concentrations of $\mathrm{Al}, \mathrm{Co}, \mathrm{Cu}, \mathrm{Mo}, \mathrm{Nb}, \mathrm{Ti}, \mathrm{V}$, and $\mathrm{W}$ and investigated the alloying effects on the single and polycrystalline elastic constants of the $\mathrm{Fe}-\mathrm{Cr}-\mathrm{Ni}$ system.

\subsection{Single-Crystal Elastic Constants}

Dyson and Holmes [37] applied X-ray methods to an austenite standard of known lattice parameter, and they observed predominantly linear variation in the lattice parameter with variation in the amount of alloying element in the austenite steel. They performed linear multiple regression analysis. The variation in the lattice parameter of austenite with respect to the atom $\%$ values of alloying elements using regression analysis was

$$
\begin{gathered}
a(\AA)=3.577+0.0065 \mathrm{C}+0.0010 \mathrm{Mn}-0.0002 \mathrm{Ni}+0.0006 \mathrm{Cr}+0.0056 \mathrm{~N}+0.0028 \mathrm{Al}- \\
0.004 \mathrm{Co}+0.0014 \mathrm{Cu}+0.0053 \mathrm{Mo}+0.0079 \mathrm{Nb}+0.0032 \mathrm{Ti}+0.0017 \mathrm{~V}+0.0057 \mathrm{~W} .
\end{gathered}
$$

According to Equation (7), $\mathrm{Al}, \mathrm{Cu}, \mathrm{Mo}, \mathrm{Nb}, \mathrm{Ti}, \mathrm{V}$, and $\mathrm{W}$ dopants enlarge the lattice parameter of austenite steel, while Co deceases it. In Figure 2, using Equation (7), we display the changes in the equilibrium lattice parameter for paramagnetic fcc $\mathrm{Fe}_{0.6-x} \mathrm{Cr}_{0.2} \mathrm{Ni}_{0.2} \mathrm{M}_{x}(\mathrm{M}=\mathrm{Al}, \mathrm{Co}, \mathrm{Cu}, \mathrm{Mo}, \mathrm{Nb}, \mathrm{Ti}, \mathrm{V}$, and $\mathrm{W} ; 0 \leq x \leq 0.08$ ) quaternary alloys relative to the paramagnetic fcc $\mathrm{Fe}_{0.6} \mathrm{Cr}_{0.2} \mathrm{Ni}_{0.2}$ ternary alloy as a function of the atomic concentrations $x$ of alloying elements. The numerical values of the lattice parameters, based on Equation (7), of the paramagnetic fcc $\mathrm{Fe}_{0.6-x} \mathrm{Cr}_{0.2} \mathrm{Ni}_{0.2}$-based alloys are listed in Tables 2 and 3.

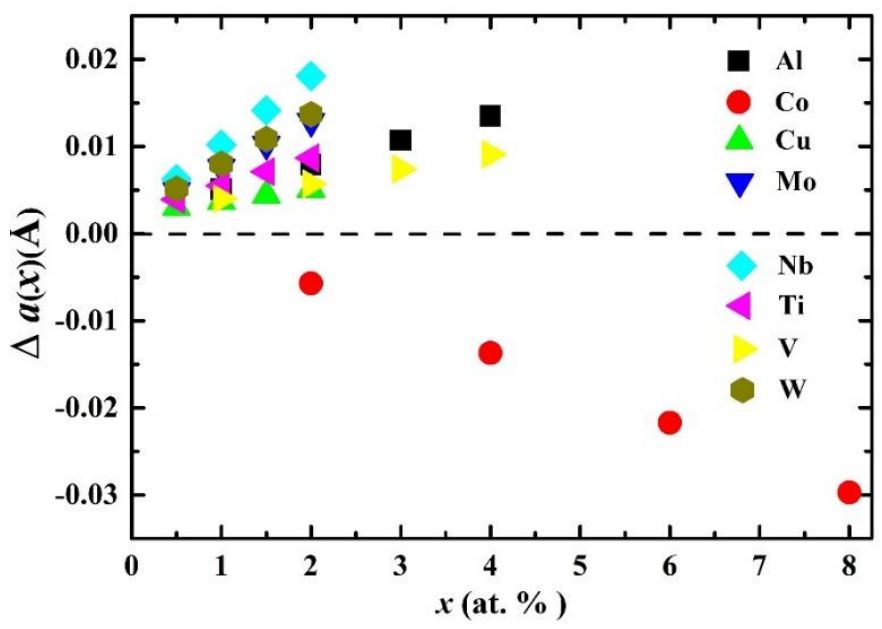

Figure 2. Changes in the equilibrium lattice parameters $(a(x))$, based on Equation (7), of paramagnetic fcc $\mathrm{Fe}_{0.6-x} \mathrm{Cr}_{0.2} \mathrm{Ni}_{0.2} \mathrm{M}_{x}$ (where $\mathrm{M}=\mathrm{Al}, \mathrm{Co}, \mathrm{Cu}, \mathrm{Mo}, \mathrm{Nb}, \mathrm{Ti}, \mathrm{V}$, and $\mathrm{W} ; 0 \leq x \leq 0.08$ ) quaternary alloys relative to the paramagnetic fcc $\mathrm{Fe}_{0.6} \mathrm{Cr}_{0.2} \mathrm{Ni}_{0.2}$ ternary alloy as a function of atomic concentration $x$. 
Table 2. Theoretical (EMTO) single-crystal elastic constants (in GPa) for paramagnetic fcc $\mathrm{Fe}-20 \mathrm{Cr}-20 \mathrm{Ni}-x \% \mathrm{M}(\mathrm{M}=\mathrm{Al}, \mathrm{Co}, \mathrm{Cu}, \mathrm{Mo}, \mathrm{Nb}, \mathrm{Ti}, \mathrm{V}$, and $\mathrm{W} ; 0 \leq x \leq 8$, where $x$ is in atom \%) alloys calculated at their lattice parameter $a_{\exp }$ (in $\AA$ ) estimated from Equation (7).

\begin{tabular}{|c|c|c|c|c|c|}
\hline System & $a_{\exp }$ & $C_{11}$ & $C_{12}$ & $C^{\prime}$ & $C_{44}$ \\
\hline $\mathrm{Fe}-20 \mathrm{Cr}-20 \mathrm{Ni}$ & 3.583 & 177 & 124 & 26.6 & 131 \\
\hline $\mathrm{Fe}-20 \mathrm{Cr}-20 \mathrm{Ni}-1.0 \mathrm{Al}$ & 3.588 & 176 & 125 & 25.4 & 130 \\
\hline $\mathrm{Fe}-20 \mathrm{Cr}-20 \mathrm{Ni}-2.0 \mathrm{Al}$ & 3.591 & 176 & 127 & 24.6 & 129 \\
\hline $\mathrm{Fe}-20 \mathrm{Cr}-20 \mathrm{Ni}-3.0 \mathrm{Al}$ & 3.593 & 176 & 129 & 23.2 & 129 \\
\hline $\mathrm{Fe}-20 \mathrm{Cr}-20 \mathrm{Ni}-4.0 \mathrm{Al}$ & 3.596 & 177 & 131 & 22.8 & 128 \\
\hline $\mathrm{Fe}-20 \mathrm{Cr}-20 \mathrm{Ni}-2.0 \mathrm{Co}$ & 3.577 & 183 & 125 & 28.7 & 136 \\
\hline $\mathrm{Fe}-20 \mathrm{Cr}-20 \mathrm{Ni}-4.0 \mathrm{Co}$ & 3.569 & 190 & 128 & 30.8 & 140 \\
\hline $\mathrm{Fe}-20 \mathrm{Cr}-20 \mathrm{Ni}-6.0 \mathrm{Co}$ & 3.561 & 197 & 131 & 32.7 & 145 \\
\hline $\mathrm{Fe}-20 \mathrm{Cr}-20 \mathrm{Ni}-8.0 \mathrm{Co}$ & 3.553 & 204 & 134 & 34.9 & 149 \\
\hline $\mathrm{Fe}-20 \mathrm{Cr}-20 \mathrm{Ni}-0.5 \mathrm{Cu}$ & 3.586 & 177 & 124 & 26.5 & 130 \\
\hline $\mathrm{Fe}-20 \mathrm{Cr}-20 \mathrm{Ni}-1.0 \mathrm{Cu}$ & 3.586 & 177 & 125 & 26.1 & 130 \\
\hline $\mathrm{Fe}-20 \mathrm{Cr}-20 \mathrm{Ni}-1.5 \mathrm{Cu}$ & 3.587 & 178 & 126 & 25.9 & 129 \\
\hline $\mathrm{Fe}-20 \mathrm{Cr}-20 \mathrm{Ni}-2.0 \mathrm{Cu}$ & 3.588 & 178 & 127 & 25.6 & 129 \\
\hline $\mathrm{Fe}-20 \mathrm{Cr}-20 \mathrm{Ni}-0.5 \mathrm{Mo}$ & 3.588 & 181 & 128 & 26.3 & 130 \\
\hline $\mathrm{Fe}-20 \mathrm{Cr}-20 \mathrm{Ni}-1.0 \mathrm{Mo}$ & 3.590 & 181 & 129 & 25.9 & 130 \\
\hline $\mathrm{Fe}-20 \mathrm{Cr}-20 \mathrm{Ni}-1.5 \mathrm{Mo}$ & 3.593 & 181 & 130 & 25.4 & 130 \\
\hline $\mathrm{Fe}-20 \mathrm{Cr}-20 \mathrm{Ni}-2.0 \mathrm{Mo}$ & 3.596 & 180 & 130 & 25.0 & 130 \\
\hline $\mathrm{Fe}-20 \mathrm{Cr}-20 \mathrm{Ni}-0.5 \mathrm{Nb}$ & 3.589 & 176 & 124 & 25.9 & 130 \\
\hline $\mathrm{Fe}-20 \mathrm{Cr}-20 \mathrm{Ni}-1.0 \mathrm{Nb}$ & 3.593 & 176 & 126 & 24.8 & 129 \\
\hline $\mathrm{Fe}-20 \mathrm{Cr}-20 \mathrm{Ni}-1.5 \mathrm{Nb}$ & 3.597 & 175 & 127 & 24.0 & 128 \\
\hline $\mathrm{Fe}-20 \mathrm{Cr}-20 \mathrm{Ni}-2.0 \mathrm{Nb}$ & 3.601 & 176 & 129 & 23.2 & 127 \\
\hline $\mathrm{Fe}-20 \mathrm{Cr}-20 \mathrm{Ni}-0.5 \mathrm{Ti}$ & 3.587 & 177 & 126 & 25.8 & 130 \\
\hline $\mathrm{Fe}-20 \mathrm{Cr}-20 \mathrm{Ni}-1.0 \mathrm{Ti}$ & 3.588 & 176 & 126 & 24.9 & 129 \\
\hline $\mathrm{Fe}-20 \mathrm{Cr}-20 \mathrm{Ni}-1.5 \mathrm{Ti}$ & 3.590 & 177 & 128 & 24.2 & 128 \\
\hline $\mathrm{Fe}-20 \mathrm{Cr}-20 \mathrm{Ni}-2.0 \mathrm{Ti}$ & 3.591 & 176 & 129 & 23.4 & 128 \\
\hline $\mathrm{Fe}-20 \mathrm{Cr}-20 \mathrm{Ni}-1.0 \mathrm{~V}$ & 3.587 & 176 & 124 & 25.8 & 130 \\
\hline $\mathrm{Fe}-20 \mathrm{Cr}-20 \mathrm{Ni}-2.0 \mathrm{~V}$ & 3.588 & 177 & 127 & 24.8 & 129 \\
\hline $\mathrm{Fe}-20 \mathrm{Cr}-20 \mathrm{Ni}-3.0 \mathrm{~V}$ & 3.590 & 177 & 128 & 24.0 & 128 \\
\hline $\mathrm{Fe}-20 \mathrm{Cr}-20 \mathrm{Ni}-4.0 \mathrm{~V}$ & 3.592 & 177 & 130 & 23.5 & 127 \\
\hline $\mathrm{Fe}-20 \mathrm{Cr}-20 \mathrm{Ni}-0.5 \mathrm{~W}$ & 3.588 & 179 & 126 & 26.3 & 131 \\
\hline $\mathrm{Fe}-20 \mathrm{Cr}-20 \mathrm{Ni}-1.0 \mathrm{~W}$ & 3.591 & 181 & 129 & 26.0 & 131 \\
\hline $\mathrm{Fe}-20 \mathrm{Cr}-20 \mathrm{Ni}-1.5 \mathrm{~W}$ & 3.594 & 182 & 131 & 25.5 & 131 \\
\hline $\mathrm{Fe}-20 \mathrm{Cr}-20 \mathrm{Ni}-2.0 \mathrm{~W}$ & 3.596 & 184 & 134 & 25.0 & 131 \\
\hline
\end{tabular}


Table 3. Theoretical (EMTO) polycrystalline elastic constants $B, G$, and $E$ (in GPa); Poisson's ratio $v$; and $B / G$ ratio for paramagnetic fcc $\mathrm{Fe}-20 \mathrm{Cr}-20 \mathrm{Ni}-x \% \mathrm{M}(\mathrm{M}=\mathrm{Al}, \mathrm{Co}, \mathrm{Cu}, \mathrm{Mo}, \mathrm{Nb}, \mathrm{Ti}, \mathrm{V}$, and $\mathrm{W}$; $0 \leq x \leq 8$, where $x$ is in atom \%) calculated at their experimental lattice parameter $a_{\exp }$ [37] (in $\AA$ ).

\begin{tabular}{|c|c|c|c|c|c|c|}
\hline System & $a_{\exp }$ & $B$ & $G$ & $B / G$ & $E$ & $v$ \\
\hline $\mathrm{Fe}-20 \mathrm{Cr}-20 \mathrm{Ni}$ & 3.583 & 142 & 70.1 & 2.03 & 181 & 0.288 \\
\hline $\mathrm{Fe}-20 \mathrm{Cr}-20 \mathrm{Ni}-1.0 \mathrm{Al}$ & 3.588 & 142 & 68.6 & 2.06 & 177 & 0.292 \\
\hline $\mathrm{Fe}-20 \mathrm{Cr}-20 \mathrm{Ni}-2.0 \mathrm{Al}$ & 3.591 & 143 & 67.6 & 2.12 & 175 & 0.296 \\
\hline $\mathrm{Fe}-20 \mathrm{Cr}-20 \mathrm{Ni}-3.0 \mathrm{Al}$ & 3.593 & 145 & 66.0 & 2.19 & 172 & 0.302 \\
\hline $\mathrm{Fe}-20 \mathrm{Cr}-20 \mathrm{Ni}-4.0 \mathrm{Al}$ & 3.596 & 146 & 65.4 & 2.24 & 171 & 0.305 \\
\hline $\mathrm{Fe}-20 \mathrm{Cr}-20 \mathrm{Ni}-2.0 \mathrm{Co}$ & 3.577 & 145 & 73.7 & 1.96 & 189 & 0.282 \\
\hline $\mathrm{Fe}-20 \mathrm{Cr}-20 \mathrm{Ni}-4.0 \mathrm{Co}$ & 3.569 & 149 & 77.1 & 1.93 & 197 & 0.279 \\
\hline $\mathrm{Fe}-20 \mathrm{Cr}-20 \mathrm{Ni}-6.0 \mathrm{Co}$ & 3.561 & 153 & 80.5 & 1.90 & 206 & 0.276 \\
\hline $\mathrm{Fe}-20 \mathrm{Cr}-20 \mathrm{Ni}-8.0 \mathrm{Co}$ & 3.553 & 157 & 84.1 & 1.87 & 214 & 0.273 \\
\hline $\mathrm{Fe}-20 \mathrm{Cr}-20 \mathrm{Ni}-0.5 \mathrm{Cu}$ & 3.586 & 141 & 69.8 & 2.03 & 180 & 0.288 \\
\hline $\mathrm{Fe}-20 \mathrm{Cr}-20 \mathrm{Ni}-1.0 \mathrm{Cu}$ & 3.586 & 142 & 69.3 & 2.05 & 179 & 0.290 \\
\hline $\mathrm{Fe}-20 \mathrm{Cr}-20 \mathrm{Ni}-1.5 \mathrm{Cu}$ & 3.587 & 143 & 68.9 & 2.07 & 178 & 0.292 \\
\hline $\mathrm{Fe}-20 \mathrm{Cr}-20 \mathrm{Ni}-2.0 \mathrm{Cu}$ & 3.588 & 144 & 68.5 & 2.10 & 177 & 0.295 \\
\hline $\mathrm{Fe}-20 \mathrm{Cr}-20 \mathrm{Ni}-0.5 \mathrm{Mo}$ & 3.588 & 146 & 69.6 & 2.10 & 180 & 0.294 \\
\hline $\mathrm{Fe}-20 \mathrm{Cr}-20 \mathrm{Ni}-1.0 \mathrm{Mo}$ & 3.590 & 147 & 69.2 & 2.12 & 180 & 0.296 \\
\hline $\mathrm{Fe}-20 \mathrm{Cr}-20 \mathrm{Ni}-1.5 \mathrm{Mo}$ & 3.593 & 147 & 68.6 & 2.14 & 178 & 0.298 \\
\hline $\mathrm{Fe}-20 \mathrm{Cr}-20 \mathrm{Ni}-2.0 \mathrm{Mo}$ & 3.596 & 147 & 68.2 & 2.15 & 177 & 0.299 \\
\hline $\mathrm{Fe}-20 \mathrm{Cr}-20 \mathrm{Ni}-0.5 \mathrm{Nb}$ & 3.589 & 141 & 69.0 & 2.04 & 178 & 0.290 \\
\hline $\mathrm{Fe}-20 \mathrm{Cr}-20 \mathrm{Ni}-1.0 \mathrm{Nb}$ & 3.593 & 143 & 67.7 & 2.10 & 175 & 0.295 \\
\hline $\mathrm{Fe}-20 \mathrm{Cr}-20 \mathrm{Ni}-1.5 \mathrm{Nb}$ & 3.597 & 143 & 66.5 & 2.16 & 173 & 0.299 \\
\hline $\mathrm{Fe}-20 \mathrm{Cr}-20 \mathrm{Ni}-2.0 \mathrm{Nb}$ & 3.601 & 145 & 65.4 & 2.22 & 171 & 0.304 \\
\hline $\mathrm{Fe}-20 \mathrm{Cr}-20 \mathrm{Ni}-0.5 \mathrm{Ti}$ & 3.587 & 143 & 69.1 & 2.07 & 178 & 0.292 \\
\hline $\mathrm{Fe}-20 \mathrm{Cr}-20 \mathrm{Ni}-1.0 \mathrm{Ti}$ & 3.588 & 142 & 68.0 & 2.09 & 176 & 0.294 \\
\hline $\mathrm{Fe}-20 \mathrm{Cr}-20 \mathrm{Ni}-1.5 \mathrm{Ti}$ & 3.590 & 144 & 66.9 & 2.16 & 174 & 0.299 \\
\hline $\mathrm{Fe}-20 \mathrm{Cr}-20 \mathrm{Ni}-2.0 \mathrm{Ti}$ & 3.591 & 145 & 65.9 & 2.20 & 172 & 0.303 \\
\hline $\mathrm{Fe}-20 \mathrm{Cr}-20 \mathrm{Ni}-1.0 \mathrm{~V}$ & 3.587 & 142 & 69.0 & 2.05 & 178 & 0.290 \\
\hline $\mathrm{Fe}-20 \mathrm{Cr}-20 \mathrm{Ni}-2.0 \mathrm{~V}$ & 3.588 & 144 & 67.8 & 2.12 & 176 & 0.297 \\
\hline $\mathrm{Fe}-20 \mathrm{Cr}-20 \mathrm{Ni}-3.0 \mathrm{~V}$ & 3.590 & 145 & 66.6 & 2.18 & 173 & 0.301 \\
\hline $\mathrm{Fe}-20 \mathrm{Cr}-20 \mathrm{Ni}-4.0 \mathrm{~V}$ & 3.592 & 146 & 65.8 & 2.22 & 172 & 0.304 \\
\hline $\mathrm{Fe}-20 \mathrm{Cr}-20 \mathrm{Ni}-0.5 \mathrm{~W}$ & 3.588 & 144 & 69.7 & 2.06 & 180 & 0.291 \\
\hline $\mathrm{Fe}-20 \mathrm{Cr}-20 \mathrm{Ni}-1.0 \mathrm{~W}$ & 3.591 & 146 & 69.6 & 2.10 & 180 & 0.295 \\
\hline $\mathrm{Fe}-20 \mathrm{Cr}-20 \mathrm{Ni}-1.5 \mathrm{~W}$ & 3.594 & 148 & 69.1 & 2.15 & 179 & 0.298 \\
\hline $\mathrm{Fe}-20 \mathrm{Cr}-20 \mathrm{Ni}-2.0 \mathrm{~W}$ & 3.596 & 151 & 68.7 & 2.20 & 179 & 0.302 \\
\hline
\end{tabular}

Figure 3 represents the theoretical changes in single-crystal elastic constants (i.e., $\Delta C_{i j}(x)=$ $\left.C_{i j}\left(\mathrm{Fe}_{0.6-x} \mathrm{Cr}_{0.2} \mathrm{Ni}_{0.2} \mathrm{M}_{x}\right)-C_{i j}\left(\mathrm{Fe}_{0.6} \mathrm{Cr}_{0.2} \mathrm{Ni}_{0.2}\right)\right)$ of paramagnetic fcc $\mathrm{Fe}_{0.6-x} \mathrm{Cr}_{0.2} \mathrm{Ni}_{0.2} \mathrm{M}_{x}(\mathrm{M}=\mathrm{Al}, \mathrm{Co}, \mathrm{Cu}$, $\mathrm{Mo}, \mathrm{Nb}, \mathrm{Ti}, \mathrm{V}$, and $\mathrm{W} ; 0 \leq x \leq 0.08)$ random alloys relative to the paramagnetic fcc $\mathrm{Fe}_{0.6} \mathrm{Cr}_{0.2} \mathrm{Ni}_{0.2}$ random alloy. In Table 2, we list the numerical values for $C_{11}, C_{12}, C^{\prime}$, and $C_{44}$ of paramagnetic fcc $\mathrm{Fe}_{0.6-x} \mathrm{Cr}_{0.2} \mathrm{Ni}_{0.2}$-based alloys calculated at their corresponding equilibrium lattice parameter $a_{\text {exp }}$. 

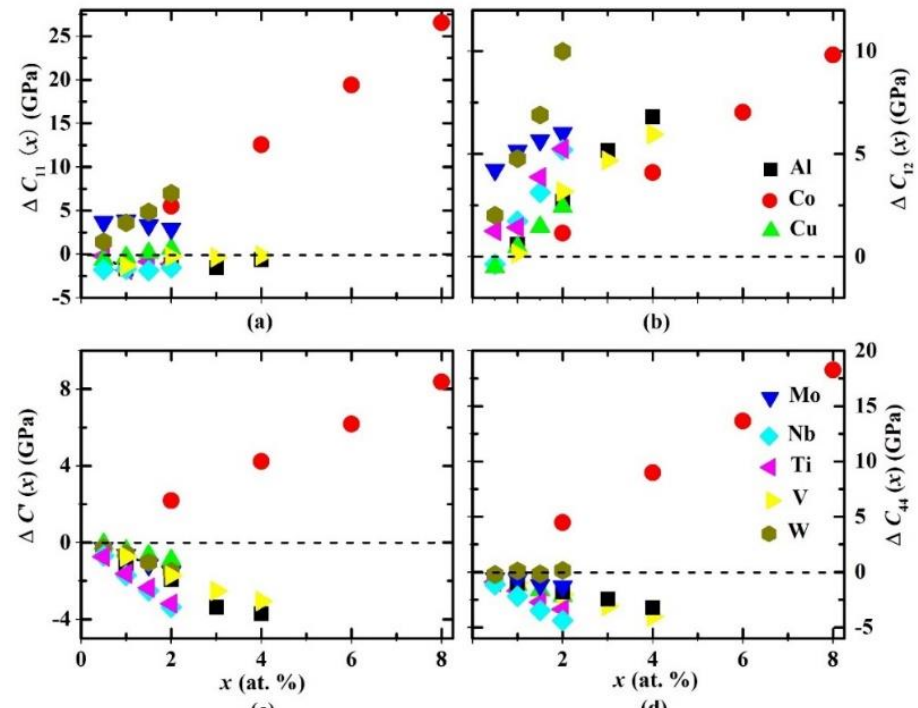

(c)

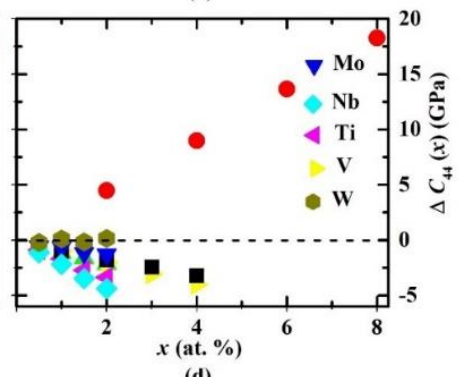

(d)

Figure 3. Theoretical changes in single-crystal elastic constants (a) $\Delta C_{11}(x),(\mathbf{b}) \Delta C_{12}(x),(\mathbf{c}) \Delta C^{\prime}(x)$, and (d) $\Delta C_{44}(x)$ of paramagnetic fcc $\mathrm{Fe}_{0.6-x} \mathrm{Cr}_{0.2} \mathrm{Ni}_{0.2} \mathrm{M}_{x}(\mathrm{M}=\mathrm{Al}, \mathrm{Co}, \mathrm{Cu}, \mathrm{Mo}, \mathrm{Nb}, \mathrm{Ti}$, V, and $\mathrm{W}$; $0 \leq x \leq 0.08)$ quaternary alloys relative to the paramagnetic fcc $\mathrm{Fe}_{0.6} \mathrm{Cr}_{0.2} \mathrm{Ni}_{0.2}$ ternary alloy as a function of atomic concentration $x$.

Investigating Figure 3 and Table 2, we observe that when adding 2.0 (0.5), 4.0 (1.0), 6.0 (1.5), and $8.0(2.0)$ atom $\%$ of $\mathrm{Co}(\mathrm{W})$ to the paramagnetic fcc $\mathrm{Fe}-\mathrm{Cr}-\mathrm{Ni}$ alloy, the theoretical $\mathrm{C}_{11}$ increases by 5.5 (1.5), 12.6 (3.6), 19.4 (4.9), and 53.6 (7.0) GPa, respectively. Aluminum, copper, niobium, titanium, and vanadium were found to have negligible effects on the $C_{11}$ value of the paramagnetic fcc Fe-Cr-Ni alloy. It is interesting to note that when substituting 0.5 atom \% of Mo for $\mathrm{Fe}$ in the $\mathrm{Fe}_{0.6} \mathrm{Cr}_{0.2} \mathrm{Ni}_{0.2}$ alloy, the $C_{11}$ increases by $3.7 \mathrm{GPa}$, but further substitution of Mo (1.0, 1.5, and 2.0 atom \%) for Fe has no effect on the $C_{11}$ of the $\mathrm{Fe}_{0.6} \mathrm{Cr}_{0.2} \mathrm{Ni}_{0.2}$ alloy.

The calculated $C_{12}$ of the fcc Fe-Cr-Ni alloy increased with all alloying elements considered. Namely, the addition of 1.0, 2.0, 3.0, and 4.0 atom \% of $\mathrm{Al}(\mathrm{V})$ to the $\mathrm{Fe}_{0.6} \mathrm{Cr}_{0.2} \mathrm{Ni}_{0.2}$ alloy enhanced the $C_{12}$ value by $0.6(0.2), 2.7(3.2), 5.2(4.7)$, and 6.8 (6) GPa, respectively. Cobalt and tungsten had pronounced effects on the $C_{12}$ value: adding $2.0(0.5), 4.0(1.0), 6.0(1.5)$, and $8.0(2.0)$ atom \% of $\mathrm{Co}(\mathrm{W})$ to $\mathrm{Fe}_{0.6} \mathrm{Cr}_{0.2} \mathrm{Ni}_{0.2}$ alloy yielded $\Delta C_{12}=1.2$ (2), $4.1(4.8), 7(6.9)$, and 9.8 (10) GPa. Substituting 0.5 atom $\%$ to 2.0 atom \% of $\mathrm{Cu}, \mathrm{Mo}, \mathrm{Nb}$, and $\mathrm{Ti}$ for $\mathrm{Fe}$ in the $\mathrm{Fe}_{0.6} \mathrm{Cr}_{0.2} \mathrm{Ni}_{0.2}$ alloy increased $C_{12}$ from $\sim 1.2 \mathrm{GPa}$ to $\sim 4.4 \mathrm{GPa}$.

We then investigated the alloying effects on the shear elastic constant $C_{44}$ of the $\mathrm{Fe}_{0.6} \mathrm{Cr}_{0.2} \mathrm{Ni}_{0.2}$ alloy, and we found that $C_{0}$ is the only alloying element that enhanced $C_{44}$. Adding 2.0, 4.0, 6.0, and 8.0 atom \% of $\mathrm{Co}$ to the $\mathrm{Fe}_{0.6} \mathrm{Cr}_{0.2} \mathrm{Ni}_{0.2}$ alloy increased the $C_{44}$ value by 4.5, 9.0, 13.7, and $18.3 \mathrm{GPa}$, respectively. Negative alloying effects on $\mathrm{C}_{44}$ of the fcc $\mathrm{Fe}-\mathrm{Cr}-\mathrm{Ni}$ alloy occurred for $\mathrm{Al}, \mathrm{Cu}, \mathrm{Mo}, \mathrm{Nb}, \mathrm{Ti}$, and V. Substituting 1.0, 2.0, 3.0, and 4.0 atom \% of $\mathrm{Al}(\mathrm{V})$ for $\mathrm{Fe}$ in the $\mathrm{Fe}_{0.6} \mathrm{Cr}_{0.2} \mathrm{Ni}_{0.2}$ alloy reduced the $C_{44}$ value by $1.0(1.0), 1.8(2.0), 2.5(3.0)$, and $3.2(4.0) \mathrm{GPa}$, respectively. On the other hand, adding 0.5 atom $\%$ to 2 atom $\%$ of $\mathrm{Cu}, \mathrm{Mo}, \mathrm{Nb}$, and Ti changed $\Delta \mathrm{C}_{44}$ from approximately $-0.6 \mathrm{GPa}$ to $-3.4 \mathrm{GPa}$. Tungsten was found to have a negligible effect on $C_{44}$.

The tetragonal shear elastic constant $C^{\prime}$ is often used to describe the stability of cubic solids. Positive (negative) values of $C^{\prime}$ indicate a stable (unstable) structure. Investigating Figure 3, we observed that Co addition increased the $C^{\prime}$ value of paramagnetic fcc Fe-Cr-Ni alloy, while $\mathrm{Al}, \mathrm{Cu}, \mathrm{Mo}, \mathrm{Nb}, \mathrm{Ti}, \mathrm{V}$, and $\mathrm{W}$ additions decreased it. Adding 2.0, 4.0, 6.0, and 8.0 atom \% of $\mathrm{Co}$ to $\mathrm{Fe}_{0.6} \mathrm{Cr}_{0.2} \mathrm{Ni}_{0.2}$ enhanced $\mathrm{C}^{\prime}$ by $2.1,3.5,6.1$, and $8.3 \mathrm{GPa}$, while substituting 1.0, 2.0, 3.0, and 4.0 atom \% of $\mathrm{Al}(\mathrm{V})$ for $\mathrm{Fe}$ in the $\mathrm{Fe}_{0.6} \mathrm{Cr}_{0.2} \mathrm{Ni}_{0.2}$ alloy reduced the $C^{\prime}$ value by $1.2(0.8), 2$ (1.8), $3.4(2.6)$, and 3.8 (3.1) GPa. The effects of the other alloying elements were similar to those of $\mathrm{Al}$ and $\mathrm{V}$. Adding 0.5 atom $\%$ to 2 atom $\%$ of $\mathrm{Cu}, \mathrm{Mo}$, $\mathrm{Nb}$, $\mathrm{Ti}$, or $\mathrm{W}$ to the $\mathrm{Fe}-\mathrm{Cr}-\mathrm{Ni}$ alloy changed the $\Delta C^{\prime}$ from approximately $-0.1 \mathrm{GPa}$ to approximately 
-3.4 GPa, respectively. According to our calculations of $C^{\prime}$, we may conclude that the paramagnetic fcc $\mathrm{Fe}-\mathrm{Cr}-\mathrm{Ni}$ alloy becomes dynamically more stable with $\mathrm{Co}$ addition and less stable with $\mathrm{Al}, \mathrm{Cu}, \mathrm{Nb}$, $\mathrm{Mo}, \mathrm{Ti}, \mathrm{V}$, and $\mathrm{W}$ dopants.

The tetragonal shear elastic constant $C^{\prime}$ is connected to the structural energy difference $\Delta E$ (i.e., $\left.\Delta E=E_{\mathrm{bcc}}-E_{\mathrm{fcc}}\right)$ between the bcc and fcc lattices. The values of $C^{\prime}$ can be obtained from the curvature around the energy minimum along a constant-volume Bain path. In fact, the Bain path [38] is a martensitic path that connects the fcc and bcc lattices which can be described as a body-centered tetragonal (bct) structure; when the $c / a$ ratio of the bct structure is 1 , the structure is bcc, while when the $c / a$ ratio reaches $\sqrt{2}$, the structure is called an fcc structure. We can understand the trends of the $C^{\prime}$ elastic constants by understanding the trends of $\Delta E$. In Figure 4, we plot the $C^{\prime}$ of fcc (solid symbols) and bcc (open symbols) lattices of paramagnetic Fe-Cr-Ni-based alloys and $\Delta E$ (i.e., $\Delta E=E_{\mathrm{bcc}}-E_{\mathrm{fcc}}$ ).

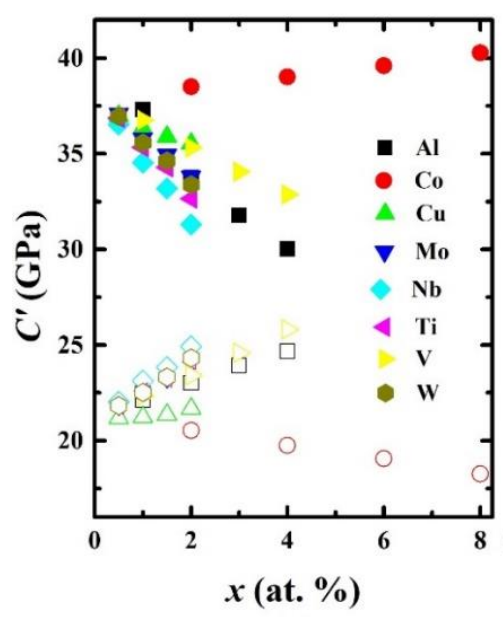

(a)

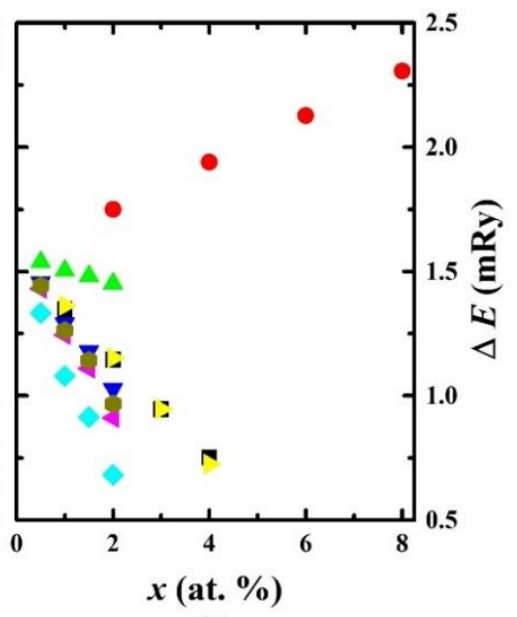

(b)

Figure 4. (a) Calculated fcc (solid symbols) and bcc (open symbols) tetragonal shear constant $C^{\prime}$ values and (b) the calculated total energy difference $\Delta E\left(\Delta E=E_{\mathrm{bcc}}-E_{\mathrm{fcc}}\right)$ between the bcc and fcc structures of paramagnetic $\mathrm{Fe}_{0.6-x} \mathrm{Cr}_{0.2} \mathrm{Ni}_{0.2} \mathrm{M}_{x}(\mathrm{M}=\mathrm{Al}, \mathrm{Co}, \mathrm{Cu}, \mathrm{Mo}, \mathrm{Nb}, \mathrm{Ti}, \mathrm{V}$, and $\mathrm{W} ; 0 \leq x \leq 0.08)$ quaternary alloys as a function of atomic concentration $x$.

Lacking experimental volume data for the paramagnetic bcc $\mathrm{Fe}_{0.6-x} \mathrm{Cr}_{0.2} \mathrm{Ni}_{0.2} \mathrm{M}_{x}(\mathrm{M}=\mathrm{Al}, \mathrm{Co}, \mathrm{Cu}$, $\mathrm{Mo}, \mathrm{Nb}, \mathrm{Ti}, \mathrm{V}$, and $\mathrm{W} ; 0 \leq x \leq 0.08$ ) random alloys, the $C^{\prime}{ }_{\mathrm{fcc}}$ and $\mathrm{C}^{\prime}{ }_{\mathrm{bcc}}$ values and the total energies $E_{\mathrm{bcc}}$ and $E_{\mathrm{fcc}}$ in Figure 4 were calculated at their theoretical equilibrium volumes.

Investigating Figure $4 \mathrm{a}$, we find that the $C^{\prime}$ values of all fcc paramagnetic $\mathrm{Fe}-\mathrm{Cr}-\mathrm{Ni}-\mathrm{M}$ alloys are larger than those of the bcc lattices, which means that for all alloys considered, the fcc structure is more stable than the bcc structure. On the other hand, alloying has an impact on increasing or decreasing the fcc and bcc tetragonal elastic constants. We observe that the $C^{\prime}{ }_{f c c}\left(C^{\prime}{ }_{b c c}\right)$ value of the Fe-Cr-Ni system increases (decreases) by addition of $\mathrm{Co}$, while other alloying elements $(\mathrm{Al}, \mathrm{Cu}, \mathrm{Mo}, \mathrm{Nb}, \mathrm{Ti}, \mathrm{V}$, and $\mathrm{W})$ reduce (enhance) the $C^{\prime}{ }_{\text {fcc }}\left(C^{\prime}{ }_{b c c}\right)$ value of the Fe-Cr-Ni system. The structural energy difference $\Delta E$ (Figure $4 \mathrm{~b}$ ) has a similar (opposite) trend to that of $C^{\prime}{ }_{\mathrm{fcc}}\left(C^{\prime}{ }_{\mathrm{bcc}}\right.$ ), with larger (smaller) values of $\Delta E$ corresponding to larger (smaller) values of $C^{\prime}{ }_{\mathrm{fcc}}\left(C^{\prime}{ }_{\mathrm{bcc}}\right)$ of the $\mathrm{Fe}-\mathrm{Cr}-\mathrm{Ni}$ system. The scaling between $C^{\prime}{ }_{\text {fcc }}\left(C^{\prime}{ }_{b c c}\right)$ and $\Delta E$ for Fe-Cr-Ni-based alloys holds. Our observations on the correlation between $C^{\prime}$ and $\Delta E$ are in line with those obtained by [39-44].

In summary, according to our calculations, the most significant effect on the $C_{11}, C_{12}, C_{44}$, and $C^{\prime}$ values of paramagnetic fcc Fe-Cr-Ni alloy was found for Co. The correlation between $C^{\prime}$ and the structural energy difference $\Delta E$ between the bcc and fcc lattices of the paramagnetic $\mathrm{Fe}-\mathrm{Cr}-\mathrm{Ni}$ system holds. 


\subsection{Polycrystalline Elastic Constants}

Theoretical changes in the polycrystalline elastic constants $(\Delta B(x), \Delta G(x), \Delta E(x))$ of paramagnetic fcc $\mathrm{Fe}_{0.6-x} \mathrm{Cr}_{0.2} \mathrm{Ni}_{0.2} \mathrm{M}_{x}(\mathrm{M}=\mathrm{Al}, \mathrm{Co}, \mathrm{Cu}, \mathrm{Mo}, \mathrm{Nb}, \mathrm{Ti}, \mathrm{V}$, and $\mathrm{W} ; 0 \leq x \leq 0.08$, where $x$ is in atom \%) random alloys relative to the paramagnetic fcc $\mathrm{Fe}_{0.6} \mathrm{Cr}_{0.2} \mathrm{Ni}_{0.2}$ random alloy and $B / G$ ratio are plotted in Figure 5. The numerical values of the polycrystalline elastic constants $(B(x), G(x), E(x)), B / G(x)$ ratio, and Poisson ratio $v(x)$ for paramagnetic fcc Fe-Cr-Ni-based alloys calculated at their experimental lattice parameters $a_{\exp }$ are listed in Table 3 .

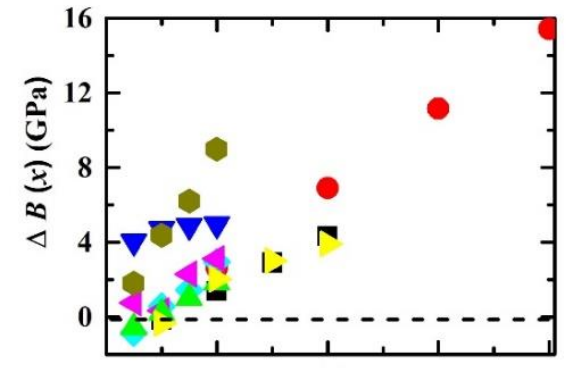

(a)

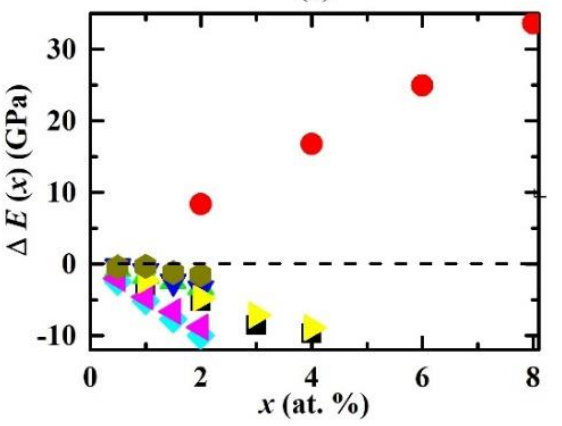

(c)

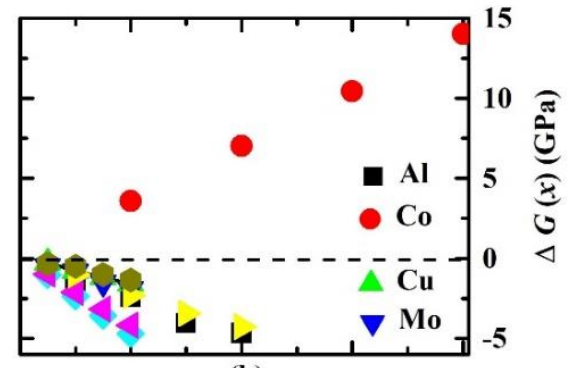

(b)

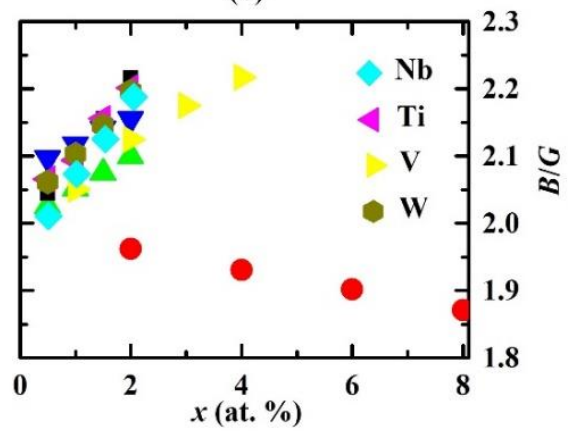

(d)

Figure 5. Theoretical changes in polycrystalline elastic constants (a) $\Delta B(x),(\mathbf{b}) \Delta G(x)$, and (c) $\Delta E(x)$ of paramagnetic fcc $\mathrm{Fe}_{0.6-x} \mathrm{Cr}_{0.2} \mathrm{Ni}_{0.2} \mathrm{M}_{x}(\mathrm{M}=\mathrm{Al}, \mathrm{Co}, \mathrm{Cu}, \mathrm{Mo}, \mathrm{Nb}, \mathrm{Ti}, \mathrm{V}$, and $\mathrm{W} ; 0 \leq x \leq 0.08)$ quaternary alloys relative to those of the paramagnetic fcc $\mathrm{Fe}_{0.6} \mathrm{Cr}_{0.2} \mathrm{Ni}_{0.2}$ ternary alloy, and (d) the $B / G$ ratio as a function of atomic concentration $x$.

In Figure 5, we observe that all alloying elements enhanced the bulk modulus of the $\mathrm{Fe}-\mathrm{Cr}-\mathrm{Ni}$ system. The greatest alloying effect was found for $\mathrm{Co}$, which increased the $B(x)$ of the Fe-Cr-Ni alloy to $3.6,6.9,11.2$, and 15.4 GPa when adding 2.0, 4.0, 6.0, and 8.0 atom \%. Aluminum and vanadium had an almost similar effect on the bulk modulus of the Fe-Cr-Ni system. Substituting 1.0, 2.0, 3.0, and 4.0 atom \% of $\mathrm{Al}(\mathrm{V})$ for $\mathrm{Fe}$ in the $\mathrm{Fe}_{0.6} \mathrm{Cr}_{0.2} \mathrm{Ni}_{0.2}$ alloy enhanced the bulk modulus by $-0.2(-0.3), 1.4(2.0)$, 2.9 (3.0), and 4.3 (3.9) GPa, respectively. Tungsten had a significant effect on the bulk modulus. Namely, adding $0.5,1.0,1.5$, and 2 atom \% of $\mathrm{W}$ to the $\mathrm{Fe}-\mathrm{Cr}-\mathrm{Ni}$ alloy enhanced the bulk modulus by 1.8, 4.4, 6.2 , and $9 \mathrm{GPa}$, respectively. Other alloying elements $(\mathrm{Cu}, \mathrm{Mo}, \mathrm{Nb}, \mathrm{Ti})$ enhanced the bulk modulus by small amounts ranging from approximately $-0.8 \mathrm{GPa}$ to approximately $5.0 \mathrm{GPa}$ depending on the alloying elements' atomic concentrations. We attribute the increase of the bulk modulus when adding transition metals $(\mathrm{Co}, \mathrm{Cu}, \mathrm{Mo}, \mathrm{Nb}, \mathrm{Ti}, \mathrm{V}, \mathrm{W})$ to the $\mathrm{Fe}-\mathrm{Cr}-\mathrm{Ni}$ alloy to the cohesion in $d$ metals using the Friedel model $[45,46]$, and also to the bond increase when going from $3 d(\mathrm{Co}, \mathrm{Cu}, \mathrm{Ti}, \mathrm{V})$ to $4 d(\mathrm{Mo}, \mathrm{Nb})$ and $5 d(\mathrm{~W})$ metals [47].

From Figure 5 and Table 3, we see that $\Delta G(x)$ and $\Delta E(x)$ have similar behavior. The variation of the shear modulus $G(x)$ and Young's modulus $E(x)$ increased when adding Co to the Fe-Cr-Ni alloy: adding 2.0-8.0 atom \% of Co raised the $G$ value ( $E$ value) of the Fe-Cr-Ni alloy by 3.6 (8.4) to 14.0 (33.6) GPa. On the other hand, $\mathrm{Al}, \mathrm{Cu}, \mathrm{Mo}, \mathrm{Nb}, \mathrm{Ti}, \mathrm{V}$, and $\mathrm{W}$ dopants reduced the $\mathrm{G}(x)$ and $E(x)$ of the Fe-Cr-Ni alloy. The largest effect on $G(x)$ and $E(x)$ of Fe-Cr-Ni-M was produced by Co. 
Investigating Figures 3 and 5, we note that the trends of $\Delta C^{\prime}(x), \Delta C_{44}(x), \Delta G(x)$, and $\Delta E(x)$ are similar but are opposite to that of $\Delta a(x)$ from Figure 2. These trends can be explained using the following assumption based on the volume effect: Since Co addition decreases the average volume per atom in $\mathrm{Fe}-\mathrm{Cr}-\mathrm{Ni}$ (see Figure 2), it is also increasing the average bond strength and, therefore, the ability of the alloy to resist shear, while additions of $\mathrm{Al}, \mathrm{Cu}, \mathrm{Nb}, \mathrm{Mo}, \mathrm{Ti}, \mathrm{V}$, and $\mathrm{W}$ have the opposite effect. The addition of $\mathrm{Al}, \mathrm{Cu}, \mathrm{Nb}, \mathrm{Mo}, \mathrm{Ti}, \mathrm{V}$, or $\mathrm{W}$ to the $\mathrm{fcc} \mathrm{Fe}-\mathrm{Cr}-\mathrm{Ni}$ alloy enlarges the lattice parameter and thus weakens the average bond strength between atoms; therefore, the ability of the alloy to resist shear decreases.

The ductile/brittle behavior of structural materials is important to their performance. Pugh [48] suggested a criterion that tests the ductility and brittleness of materials based on their bulk and shear moduli values: a material that has a $B / G$ ratio less than 1.75 is in the brittle regime; otherwise, it is in the ductile regime. From Figure 5 and Table 3, we observed that the paramagnetic fcc $\mathrm{Fe}_{0.6} \mathrm{Cr}_{0.2} \mathrm{Ni}_{0.2}$ alloy is in the ductile regime with $B / G=2.0253$. Our calculations show that $\mathrm{Al}, \mathrm{Cu}, \mathrm{Mo}, \mathrm{Nb}, \mathrm{Ti}, \mathrm{V}$, or $\mathrm{W}$ addition to the paramagnetic fcc Fe-Cr-Ni system enhances $B / G$ and increases the ductility of the system. Niobium and vanadium have the largest impact on the ductility of the Fe-Cr-Ni system: adding $2.0(4.0)$ atom $\%$ of $\mathrm{Nb}(\mathrm{V})$ raised the $B / G$ to 2.2161 (2.2167). Cobalt reduced the $B / G$ value and therefore decreased the ductility of the $\mathrm{Fe}-\mathrm{Cr}-\mathrm{Ni}$ system.

In Figure 6, we plot the theoretical Poisson's ratio $v(x)$ for paramagnetic fcc $\mathrm{Fe}_{0.6-x} \mathrm{Cr}_{0.2} \mathrm{Ni}_{0.2} \mathrm{M}_{x}$ $(\mathrm{M}=\mathrm{Al}, \mathrm{Co}, \mathrm{Cu}, \mathrm{Mo}, \mathrm{Nb}, \mathrm{Ti}, \mathrm{V}$, and $\mathrm{W} ; 0 \leq x \leq 0.08)$ random alloys as a function of atomic concentration $x$. We obtained the result that the Poisson's ratio has a similar trend to $B / G$. Adding $\mathrm{Al}, \mathrm{Cu}, \mathrm{Mo}, \mathrm{Nb}, \mathrm{Ti}$, $\mathrm{V}$, or $\mathrm{W}$ to the $\mathrm{Fe}-\mathrm{Cr}-\mathrm{Ni}$ alloy enhanced the value of $v(x)$, while Co addition decreased the $v(x)$ value of the Fe-Cr-Ni alloy. The most significant effects on the $v(x)$ value of paramagnetic fcc Fe-Cr-Ni alloy were produced by $\mathrm{Al}$ and $\mathrm{V}$.

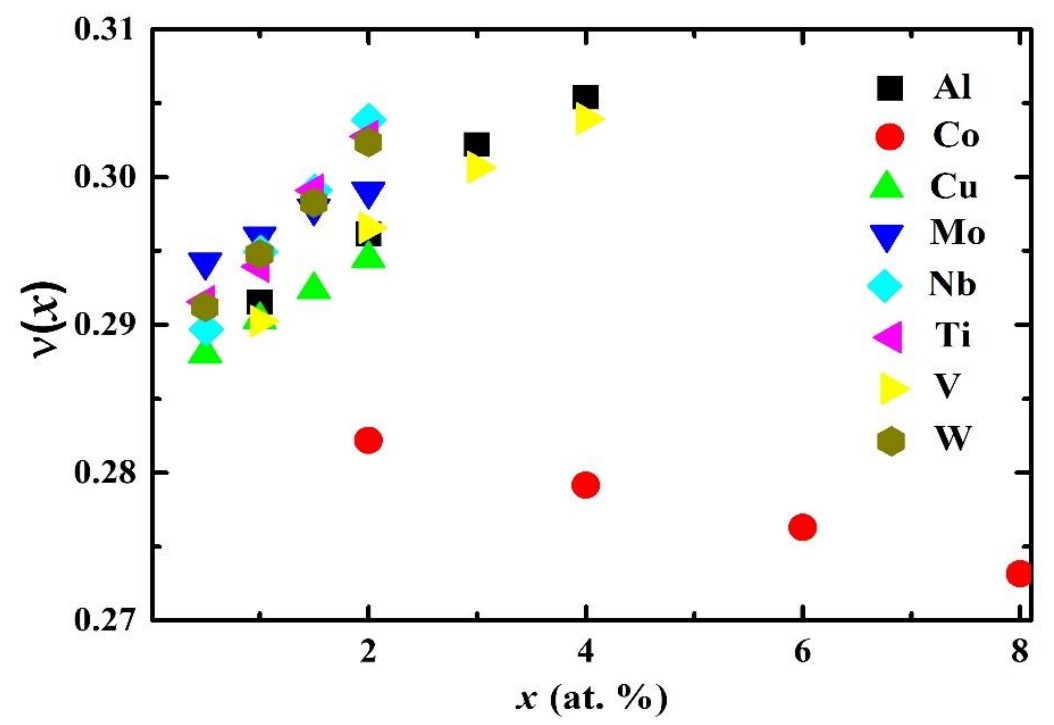

Figure 6. Theoretical Poisson's ratio $v(x)$ of paramagnetic fcc $\mathrm{Fe}_{0.6-x} \mathrm{Cr}_{0.2} \mathrm{Ni}_{0.2} \mathrm{M}_{x}(\mathrm{M}=\mathrm{Al}, \mathrm{Co}, \mathrm{Cu}, \mathrm{Mo}$, $\mathrm{Nb}, \mathrm{Ti}, \mathrm{V}$, and $\mathrm{W} ; 0 \leq x \leq 0.08)$ quaternary alloys as a function of the atomic concentration $x$.

Our results on the polycrystalline elastic constants for $\mathrm{Fe}-\mathrm{Cr}-\mathrm{Ni}-\mathrm{Mo}$ alloys are in line with those obtained by Ledbetter et al. [5], who produced ultrasonic measurements of the polycrystalline elastic constants of six fcc $\mathrm{Fe}-19 \mathrm{Cr}-12 \mathrm{Ni}$ (atom \%) alloys with Mo content ranging up to 2.4 atom \%. They found that Mo reduced the $G$ and $E$ moduli and raised the $B$ and $v$ ratio.

\section{Conclusions}

Using the exact muffin-tin orbital method with coherent potential approximation and Perdew-Burke-Ernzerhof generalized gradient approximation, we investigated the single-crystal 
and polycrystalline elastic parameters of paramagnetic fcc $\mathrm{Fe}_{0.6-x}-\mathrm{Cr}-\mathrm{Ni}-\mathrm{M}_{x}(\mathrm{M}=\mathrm{Al}, \mathrm{Co}, \mathrm{Cu}, \mathrm{Mo}, \mathrm{Nb}$, $\mathrm{Ti}, \mathrm{V}$, and $\mathrm{W} ; 0 \leq x \leq 0.08$ ) random alloys. We demonstrated that all alloying elements enhanced the elastic constant $C_{12}$ of the $\mathrm{Fe}-\mathrm{Cr}-\mathrm{Ni}$ system. Cobalt and tungsten increased the $C_{11}$ elastic constant of the $\mathrm{Fe}-\mathrm{Cr}-\mathrm{Ni}$ ternary alloy, while other alloying elements had a negligible effect. Furthermore, we found that the $C^{\prime}, C_{44}, E$, and $G$ moduli of the $\mathrm{Fe}-\mathrm{Cr}-\mathrm{Ni}$ alloy were increased by Co addition and reduced by $\mathrm{Al}, \mathrm{Cu}, \mathrm{Mo}, \mathrm{Nb}, \mathrm{Ti}, \mathrm{V}$, and $\mathrm{W}$ dopants. Tungsten had a negligible effect on $\mathrm{C}_{44}$. We obtained a correlation between $C^{\prime}$ and the structural energy difference $\Delta E$ between fcc and bcc lattices, wherein large $C^{\prime}$ corresponds to large $\Delta E$. The brittle/ductile transitions formulated by the Pugh ratio $B / G$ were also discussed. It was shown that $\mathrm{Al}, \mathrm{Cu}, \mathrm{Mo}, \mathrm{Nb}, \mathrm{Ti}, \mathrm{V}$, and $\mathrm{W}$ dopants enhanced the ductility of the Fe-Cr-Ni system, while Co enhanced the brittleness of the Fe-Cr-Ni alloy. The Poisson's ratio $v$ showed the same trend as the $B / G$ ratio, with small variations obtained in $v$ when adding alloying elements to the $\mathrm{Fe}-\mathrm{Cr}-\mathrm{Ni}$ system. Our calculations provide consistent data on the elastic properties of paramagnetic fcc $\mathrm{Fe}-\mathrm{Cr}-\mathrm{Ni}$-based alloys at low temperature and call for experimental studies on these alloys.

Funding: This research received no external funding.

Acknowledgments: I would like to thank L. Vitos for the helpful discussion. The simulations were performed using resources provided by the Swedish National Infrastructure for Computing (SNIC) at the National Supercomputer Centre in Linköping.

Conflicts of Interest: The author declares no conflict of interest.

\section{References}

1. Marshall, P. Austenitic Stainless Steel: Microstructure and Mechanical Properties; Elsevier Applied Science Publishers Ltd.: London, UK, 1984.

2. Davis, J.R. AMS Specialty Handbook: Stainless Steels; AMS International: Geauga County, OH, USA, 1994.

3. Wrangln, G. An Introduction to Corrosion and Protecting of Metals; Chapman and Hall: New York, NY, USA, 1985.

4. Majumdar, A.K.; Blanckenhagen, P.V. Magnetic phase diagram of Fe80-xNixCr20 (10 $\leq x \leq 30)$ alloys. Phys. Rev. B 1984, 29, 4079-4085.

5. Ledbetter, H.M.; Kim, S.A. Molybdenum effect on Fe-Cr-Ni-alloy elastic constants. J. Mater. Res. 1988, 3, 40-44. [CrossRef]

6. Ledbetter, H. Predicted monocrystal elastic constants of 304-type stainless steel. Physica 1985, 128, 1-4. [CrossRef]

7. Ledbetter, H.M. Sound velocities and elastic constants of steels 304, 310, and 316. Met. Sci. 1980, 14, 595-596. [CrossRef]

8. Teklu, A.; Ledbetter, H.; Kim, S.; Boatner, L.A.; McGuire, M.; Keppens, V. Single-crystal elastic constants of Fe-15Ni-15Cr alloy. Met. Mater. Trans. A 2004, 35, 3149-3154. [CrossRef]

9. Dong, Z.; Schönecker, S.; Chen, D.; Li, W.; Long, M.; Vitos, L. Elastic properties of paramagnetic austenitic steel at finite temperature: Longitudinal spin fluctuations in multicomponent alloys. Phys. Rev. B 2017, 96, 174415. [CrossRef]

10. Vitos, L. The EMTO Method and Applications, Computational Quantum Mechanics for Materials Engineers; Springer: London, UK, 2007.

11. Vitos, L.; Korzhavyi, P.A.; Johansson, B. Elastic Property Maps of Austenitic Stainless Steels. Phys. Rev. Lett. 2002, 88, 155501. [CrossRef] [PubMed]

12. Hohenberg, P.; Kohn, W. Inhomogeneous Electron Gas. Phys. Rev. 1964, 136, B864. [CrossRef]

13. Kohn, W.; Sham, L.J; Sham, L. Self-Consistent Equations Including Exchange and Correlation Effects. Phys. Rev. 1965, 140, A1133-A1138. [CrossRef]

14. Perdew, J.P.; Burke, K.; Ernzerhof, M. Generalized gradient approximation made simple. Phys. Rev. Lett. 1996, 77, 3865-3868. [CrossRef]

15. Andersen, O.K.; Jepsen, O.; Krier, G. Lectures on Methods of Electronic Structure Calculations; World Scientific Publishing: Singapore, 1994. 
16. Andersen, O.K.; Arcangeli, C.; Tank, R.W.; Saha-Dasgupta, T.; Krier, G.; Jepsen, O.; Dasgupta, I. Third-generation TB-LMTO. MRS Online Proc. Libr. Arch. 1998, 491. [CrossRef]

17. Vitos, L.; Skriver, H.; Johansson, B.; Kollár, J. Application of the exact muffin-tin orbitals theory: The spherical cell approximation. Comput. Mater. Sci. 2000, 18, 24-38. [CrossRef]

18. Vitos, L. Total-energy method based on the exact muffin-tin orbitals theory. Phys. Rev. B 2001, $64,014107$. [CrossRef]

19. Vitos, L.; Abrikosov, I.A.; Johansson, B. Anisotropic Lattice Distortions in Random Alloys from First-Principles Theory. Phys. Rev. Lett. 2001, 87, 156401. [CrossRef] [PubMed]

20. Soven, P. Coherent-Potential Model of Substitutional Disordered Alloys. Phys. Rev. 1967, 156, 809-813. [CrossRef]

21. Györffy, B.L. Coherent-Potential Approximation for a Nonoverlapping-Muffin-Tin-Potential Model of Random Substitutional Alloys. Phys. Rev. B 1972, 5, 2382-2384. [CrossRef]

22. Kollár, J.; Vitos, L.; Skriver, H.L. Electronic Structure and Physical Properties of Solids: The Uses of the LMTO Method; Lecture Notes in Physics; Springer: Berlin, Germany, 2000.

23. Gyorffy, B.L.; Pindor, A.J.; Staunton, J.; Stocks, G.M.; Winter, H. A first-principles theory of ferromagnetic phase transitions in metals. J. Phys. F Met. Phys. 1985, 15, 1337-1386. [CrossRef]

24. Zhang, H.L.; Al-Zoubi, N.; Johansson, B.; Vitos, L. Alloying effects on the elastic parameters of ferromagnetic and paramagnetic Fe from first-principles theory. J. Appl. Phys. 2011, 110, 073707. [CrossRef]

25. Zhang, H.L.; Punkkinen, M.P.J.; Johansson, B.; Hertzman, S.; Vitos, L. Single-crystal elastic constants of ferromagnetic bcc Fe-based random alloys from first-principles theory. Phys. Rev. B 2010, 81, 184105. [CrossRef]

26. Delczeg-Czirjak, E.K.; Delczeg, L.; Ropo, M.; Kokko, K.; Punkkinen, M.P.J.; Johansson, B.; Vitos, L. Ab initio study of the elastic anomalies in Pd-Ag alloys. Phys. Rev. B 2009, 79, 085107. [CrossRef]

27. Al-Zoubi, N.; Johansson, B.; Nilson, G.; Vitos, L. The Bain path of paramagnetic Fe-Cr based alloys. J. Appl. Phys. 2011, 110, 013708. [CrossRef]

28. Al-Zoubi, N.; Skorodumova, N.V.; Medvedeva, A.; Andersson, J.; Nilson, G.; Johansson, B.; Vitos, L. Tetragonality of carbon-doped ferromagnetic iron alloys: A first-principles study. Phys. Rev. B 2012, 85, 014112. [CrossRef]

29. Al-Zoubi, N.; Li, X.; Schönecker, S.; Johansson, B.; Vitos, L. Influence of manganese on the bulk properties of Fe-Cr-Mn alloys: A first-principles study. Phys. Scr. 2014, 89, 125702. [CrossRef]

30. Al-Zoubi, N.; Schönecker, S.; Johansson, B.; Vitos, L. Assessing the Exact Muffin-Tin Orbitals method for the Bain path of metals. Philos. Mag. 2017, 97, 1243-1264. [CrossRef]

31. Al-Zoubi, N. First-principles study of the structural and elastic properties of AuxV1-x and AuxNb1-x alloys. Philos. Mag. 2018, 98, 1099-1113. [CrossRef]

32. Hill, R. The Elastic Behavior of a Crystalline Aggregate. Proc. Phys. Soc. Sect. A 1952, 65, 349. [CrossRef]

33. Voigt, W. Elasticitatsconstunten isotroper Korper. Ann. Phys. 1889, 38, 573. [CrossRef]

34. Reuss, A.; Angew, Z. Berechnung der Fliehgrenze von Mischkristallen auf Grund der Plastizittitsbedingung fiir Einkristalle. Math. Phys. 1929, 9, 49-58.

35. Korzhavyi, P.A.; Ruban, A.V.; Abrikosov, I.A.; Skriver, H.L.; Korzhavyi, P. Madelung energy for random metallic alloys in the coherent potential approximation. Phys. Rev. B 1995, 51, 5773-5780. [CrossRef]

36. Moruzzi, V.L.; Janak, J.F.; Schwarz, K. Calculated thermal properties of metals. Phys. Rev. B 1988, 37, 790-799. [CrossRef]

37. Dyson, D.J.; Holmes, B. Effect of alloying additions on the lattice parameter of Austenite. J. Iron Steel Inst. 1970, 208, 469-474.

38. Bain, E.C.; Dunkirk, N.Y. The nature of martensite. Trans. Am. Inst. Min. Metall. Eng. 1924, 70, 25.

39. Söderlind, P.; Eriksson, O.; Wills, J.M.; Boring, A.M. Theory of elastic constants of cubic transition metals and alloys. Phys. Rev. B 1993, 48, 5844-5851. [CrossRef] [PubMed]

40. Söderlind, P.; Wills, J.M.; Boring, A.M.; Eriksson, O. Trends of the elastic constants of cubic transition metals. Phys. Rev. Lett. 1992, 68, 2802-2805.

41. Craievich, P.J.; Sanchez, J.M.; Watson, R.E.; Weinert, M. Structural instabilities of excited phases. Phys. Rev. $B$ 1997, 55, 787-797. [CrossRef]

42. Craievich, P.J.; Weinert, M.; Sanchez, J.M.; Watson, R.E. Local stability of nonequilibrium phases. Phys. Rev. Lett. 1994, 72, 3076-3079. [CrossRef] [PubMed] 
43. Grimvall, G.; Magyari-Köpe, B.; Ozolins, V.; Persson, K.A. Lattice instabilities in metallic elements. Rev. Mod. Phys. 2012, 84, 945-986. [CrossRef]

44. Al-Zoubi, N.; Schönecker, S.; Li, X.; Li, W.; Johansson, B.; Vitos, L. Elastic properties of 4d transition metal alloys: Values and trends. Comput. Mater. Sci. 2019, 159, 273-280. [CrossRef]

45. Kollár, J.; Vitos, L.; Johansson, B.; Skriver, H. Metal Surfaces: Surface, Step and Kink Formation Energies. Phys. Status Solidi B 2000, 217, 405-418. [CrossRef]

46. Brooks, M.S.S.; Johansson, B. Exchange integral matrices and cohesive energies of transition metal atoms. J. Phys. F Met. Phys. 1983, 13, L197-L202. [CrossRef]

47. Vitos, L.; Korzhavyi, P.A.; Johansson, B. Stainless steel optimization from quantum mechanical calculations. Nat. Mater. 2003, 2, 25-28. [CrossRef] [PubMed]

48. Pugh, S.F. XCII. Relations between elastic moduli and plastic properties of polycrystalline pure metals. Philos. Mag. 1954, 45, 823-843. [CrossRef]

(C) 2019 by the author. Licensee MDPI, Basel, Switzerland. This article is an open access article distributed under the terms and conditions of the Creative Commons Attribution (CC BY) license (http://creativecommons.org/licenses/by/4.0/). 